\title{
Consumer Preference towards Branded and Unbranded Honey in Tamil Nadu, India
}

\author{
S. Leaka ${ }^{1}$, S. Moghana Lavanya ${ }^{1 *}$, M.R. Srinivasan ${ }^{2}$ and S. Hemalatha ${ }^{1}$ \\ ${ }^{1}$ Department of Agricultural and Rural Management, Tamil Nadu Agricultural University, \\ Coimbatore, Tamil Nadu, India \\ ${ }^{2}$ Department of Agricultural Entomology, Agricultural College and Research Institute, \\ Tamil Nadu Agricultural University, Killikulam, Tamil Nadu, India
}

*Corresponding author

\begin{abstract}
A B S T R A C T

\begin{tabular}{|l|}
\hline Key w ord s \\
Honey, Brands, \\
Market \\
\hline Article Info \\
\hline Accepted: \\
17 May 2019 \\
Available Online: \\
10 June 2019 \\
\hline \hline
\end{tabular}

\section{Introduction}

Honey is a sweet, flavorful liquid obtained from the nectar of flowers collected by bees, which has high nutritional value and lot of health benefits. Earlier, honey was collected from the wild forest but presently due to its wide spread of potential uses and huge demand, it has been domesticated.

Honey industry was classified as organized and unorganized; the organized industry had well established brands with large scale production and marketing. Unorganized ones were usually produced by local beekeeper or

Honey is a natural, sweet, syrupy fluid obtained from the nectar of flowers collected by bees. The main objective of the study was to analyze consumer preference towards branded and unbranded honey in Tamil Nadu. The primary data was collected from consumers through questionnaire using online survey method. The secondary data was collected using published sources and websites. From the study it was clear that majority of the respondents preferred branded honey which was followed by wild/ tribal honey and most of them preferred Dabur honev from the available brands.
\end{abstract}


in India were Uttar Pradesh, West Bengal, Punjab, Bihar, Rajasthan, Himachal Pradesh, Kerala, etc. Tamil Nadu is one of the largest honey producers in India with the annual production of about 1820 MT (Source: www.indiastat.com). Majority of honey production is owned in Jamunamaruthur in Thiruvannamalai district and Marthandam in Kanyakumari District. The major sources for honey production in Tamil Nadu were Cardamom, Cashew, Tamarind, Rubber, Forest flora, Jamun, etc.

Some of the health benefits of honey were it helps in delaying ageing; wound healing powers, an energizer, overcome fatigue, antibacterial, antioxidant, etc ${ }^{3}$. Honey has been used throughout the world since several million years ago as it is a safe and suggestive of good health for all age groups.

The quality of honey varied on the type and variety of plants and also according to the climatic conditions. Some of the medicinal uses of honey were ${ }^{2}$ :

\section{Treats Gastroenteritis}

Cures Gastric ulcers by reducing the secretion of gastric acid

Heals wounds

Clears infections in cancer patients

Treats burns

Manages skin diseases

Remedy for stomach disorders

Honey is also widely used as sweeteners, food additives, and cosmetics. It is widely used in preparation of bakery products, preservation of fruits and vegetables, etc. Nutritional value of honey is provided (Table 1) and it indicates that the main composition of honey was carbohydrates, sugars and water.

\section{Materials and Methods}

Primary data for the study was collected through online survey method with structured and detailed questionnaire from consumers. Information from consumers was obtained using online survey with detailed questionnaire and the total sample size of the study was 301 consumers. The collected information was analyzed using percentage analysis.

\section{Results and Discussion}

The study was undertaken with the primary objective to understand the preference of different brands of honey among the sample consumers. The type of honey includes branded honey, unbranded honey, imported honey and wild/ tribal honey in the market.

The respondents were asked to choose the type of honey purchased and brands preferred. Table 2 shows that the majority of the respondents of about 41.2 per cent preferred branded honey, 17.9 per cent of the respondents preferred non branded honey, 6.3 percent of the respondents preferred imported honey and 34.6 percent of the respondents preferred Wild/Tribal honey.

Consumer honey from wide range of brands like Dabur honey, Lion honey, Himalaya forest honey, Patanjali honey, 24 Mantra honey, Vibis honey, Local branded honey, Zandu pure honey, Apis Himalaya Honey, etc. Table 3 shows that the majority of the respondents of about 20.3 percent preferred Dabur honey, followed by Patanjali honey (13.6 percent), Lion honey (13.3 percent), 6.6 per cent of the respondents preferred other brands which were locally available. Around 12.3 per cent did not prefer branded honey and 19.6 per cent of the respondents did not have any specific brand preference 
Table.1 Nutritional composition of honey

\begin{tabular}{|c|c|c|}
\hline \multicolumn{3}{|c|}{ Carbohydrates } \\
\hline S. No & Nutrient & Amount (per 100g) \\
\hline 1. & Carbohydrate & $82.40 \mathrm{~g}$ \\
\hline \multirow[t]{6}{*}{2.} & Sugars & $82.12 \mathrm{~g}$ \\
\hline & Fructose & $40.94 \mathrm{~g}$ \\
\hline & ii. Glucose (dextrose) & $35.75 \mathrm{~g}$ \\
\hline & iii. Galactose & $3.10 \mathrm{~g}$ \\
\hline & iv. Maltose & $1.44 \mathrm{~g}$ \\
\hline & v. Sucrose & $0.89 \mathrm{~g}$ \\
\hline 3. & Fiber & $0.2 \mathrm{~g}$ \\
\hline \multicolumn{3}{|c|}{ Vitamins } \\
\hline S. No & Nutrient & Amount (per 100g) \\
\hline 1. & Betaine & $1.7 \mathrm{mg}$ \\
\hline 2. & Choline & $2.2 \mathrm{mg}$ \\
\hline 3. & Niacin & $0.121 \mathrm{mg}$ \\
\hline 4. & Pantothenic acid & $0.068 \mathrm{mg}$ \\
\hline 5. & Riboflavin & $0.038 \mathrm{mg}$ \\
\hline 6. & Vitamin B6 & $0.024 \mathrm{mg}$ \\
\hline 7. & Vitamin C & $0.5 \mathrm{mg}$ \\
\hline \multicolumn{3}{|c|}{ Others } \\
\hline S.No & Nutrient & Amount (per 100g) \\
\hline 1. & Proteins & $0.30 \mathrm{~g}$ \\
\hline 2. & Ash & $0.20 \mathrm{~g}$ \\
\hline 3. & Water & $17.10 \mathrm{~g}$ \\
\hline
\end{tabular}

(Source: https://www.nutritionvalue.org)

Table.2 Type of Honey Preferred

\begin{tabular}{|l|l|c|c|}
\hline S. No & Category & Frequency & Percentage (\%) \\
\hline $\mathbf{1}$ & Branded honey & 124 & 41.2 \\
\hline $\mathbf{2}$ & Unbranded honey & 54 & 17.9 \\
\hline $\mathbf{3}$ & Imported honey & 19 & 6.3 \\
\hline $\mathbf{4}$ & Wild/Tribal honey & 104 & 34.6 \\
\hline & Total & 301 & 100 \\
\hline
\end{tabular}

Source: Primary data 
Table.3 Consumer preference towards different brands of honey

\begin{tabular}{|l|l|c|c|}
\hline S. No & Category & Frequency & Percentage (\%) \\
\hline $\mathbf{1}$ & Dabur honey & 61 & 20.30 \\
\hline $\mathbf{2}$ & Lion honey & 40 & 13.30 \\
\hline $\mathbf{3}$ & Himalaya forest honey & 13 & 4.30 \\
\hline $\mathbf{4}$ & Patanjali honey & 41 & 13.60 \\
\hline $\mathbf{5}$ & 24 Mantra honey & 9 & 3.00 \\
\hline $\mathbf{6}$ & Vibis honey & 4 & 1.30 \\
\hline $\mathbf{7}$ & Local branded honey & 5 & 3.30 \\
\hline $\mathbf{8}$ & Zandu pure honey & 2 & 1.70 \\
\hline $\mathbf{9}$ & Apis Himalaya Honey & 20 & 0.70 \\
\hline $\mathbf{1 0}$ & Others brands & 37 & 6.60 \\
\hline $\mathbf{1 1}$ & I don't prefer branded honey & 59 & 12.30 \\
\hline $\mathbf{1 2}$ & Any brand & & 19.60 \\
\hline
\end{tabular}

Source: Primary data

Bee keeping's untapped potential for increasing opportunities, steady employment and income in rural areas is yet to be utilized. From the study it was clear that majority of the respondents preferred branded honey which was followed by wild/ tribal honey and most of them preferred Dabur honey from the available brands. Presently consumers have become health conscious and preferred quality products. Farmers can explore ways to enhance their income by honey production and market their produce by forming Farmer producer companies.

\section{References}

Aparna, A. R., and Rajalakshmi, D. (1999). Honey-its characteristics, sensory aspects, and applications. Food Reviews International, 15(4), 455-471.

Bardy, J., Slevin, N. J., Mais, K. L., and Molassiotis, A. (2008). A systematic review of honey uses and its potential value within oncology care. Journal of clinical nursing, 17(19), 2604-2623

Bogdanov, S., Jurendic, T., Sieber, R., and Gallmann, P. (2008). Honey for nutrition and health: a review. Journal of the American College of Nutrition, 27(6), 677-689.

http://www.fnbnews.com/Interview/brandedhoney-in-india-growing-at-cagr-of-10says-apis-indias-anand-41306

Kumar, K. S., Bhowmik, D., Biswajit, C., and Chandira, M. R. (2010). Medicinal uses and health benefits of honey: an overview.J Chem Pharm Res, 2(1), 385-395.

Singh, N., and Bath, P. K. (1997). Quality evaluation of different types of Indian honey. Food Chemistry, 58(1-2), 129133.

\section{How to cite this article:}

Leaka, S., S. Moghana Lavanya, M.R. Srinivasan and Hemalatha, S. 2019. Consumer Preference towards Branded and Unbranded Honey in Tamil Nadu. Int.J.Curr.Microbiol.App.Sci. 8(06): 2347-2350. doi: https://doi.org/10.20546/ijcmas.2019.806.279 